\title{
Effects of Cold Water, Mechanical and Acid Scarifications on Germination and Seedling Growth of Pre-Chilled Seeds of Leucaena leucocephala
}

\author{
Muhammad Rusdy \\ Faculty of Animal Science Hasanuddin University, Jl. Perintis Kemeredekaan Km 10 Makassar, Indonesia
}

\begin{abstract}
The effects of pre-chilling on seed germination and seedling growth of Leucaena leucocephala were examined, alone and combined with soaking in cold water, clipping and immersing in concentrated sulfuric acid. Results showed that germination percentage of freshly harvested seeds was improved significantly by pre-chilling. Germination percentages of pre-chilled seeds soaked in cold water in the short duration were significantly lower than control, but their radicle length and seedling vigor index were higher. Sandpapering in conjunction with pre-chilling is the most efficient methods for high germination percentage, germination time and seedling growth index. Immersion of seeds in sulfuric until 20 minutes period had no significant effect on germination percentage, but it significantly reduced radicle length, hypocotyls length and seedling vigor index. These results confirm the earlier findings that seed dormancy in Leucaena leucocephala to be external and internal type.
\end{abstract}

Keywords: Leucaena leucocephala, pre-chilling, scarifications, germination, seedling growth

\section{Introduction}

Leucaena is tropical tree that known botanically as Leucaena leucocephala (Lam.) de Wit originated from northern central America and southern Mexico (Hughes and Colin, 1998) and at present, it has been found in almost all tropical countries. Leucaena has been called miracle tree because of its fast growth, long lived, highly nutritious forage and its great variety of uses. As well as forage, Leucaena can provide firewood, timber, human food, green manure, shade and erosion control (Shelton and Brewbaker, 1998).

Leucaena has been recognized as high potential fodder for centuries. Its dry matter yield can attain $4.23 \mathrm{t} \mathrm{ha}^{1}$ year $^{1}$ (Aminah and Wong, 2004). The plant also is a soil improver because of its ability to fix high atmospheric N. N fixation of leucaena inoculated with Rhizobium strain IRc 1045 is 133 $\mathrm{kg} / \mathrm{ha}$ for six month (Sanginga et al., 1989). Intercropping Leucaena promotes height and diameter of teak. Teak growth increases with increasing relative proportion of Leucaena in the mixture. Total soil $\mathrm{N}$ increases with increasing proportion of Leucaena in the mixture, while available $\mathrm{P}$ content of the soil increases as the proportion of Leucaena increases up to $50 \%$ (Kumar et al., 1998). The foliage contain both nutrients and roughage, and can make an almost complete animal feed, somewhat comparable to alfalfa. All Leucaena plant parts are edible to animals, including leaves, young stems, flowers, young and mature pods, and seeds. Leucaena is a rich source of protein (15$38 \%$ ) and highly digestible (60-70\%) Its crude protein has a high nutritional quality and its amino acids are comparable to those contained in soybean (U ter Meulen et al, 1985). However, although Leucaena has high dry matter yield potential and nutritive value, the presence of mimosine has limited the use of this plant as animal feed. Leucaena contains high amounts mimosine, a toxic amino acid that is detrimental to non-ruminants and non-adapted ruminants. Fortunately, ruminants in certain parts of the world such as Indonesia and Hawaii can tolerate higher dietary levels of Leucaena because of presence bacteria in their rumen that have ability to break down mimosine to unharmed compounds.

Despite of the great importance and characteristics, establishment of Leucaena is difficult. One of the major constraint in successful establishment is its high degree of hard seed due to an impermeable waxy coat which must be broken before the seed will imbibe water and germinate (Shelton and Brewbaker, 1998). The increase in seed germination as influenced by sulfuric acid scarification (Shapo, 2015) indicates that the low seed germination in fresh Leucaena seeds is caused by physical dormancy. Besides by physical dormancy, the low germination in Leucaena is also due to physiological dormancy (Omran, 2013).

A commonly treatment that practiced by farmer to reduce seed dormancy which is caused by physiological dormancy is pre-chilling. Pre-chilling has been shown can increase seed germination in some species like Papavers pecies (Golmohammadzadeh et al. 2014), Hymenocrater platystegius (Teimouri et al., 2013) and Leucaena leucocephala (Omran, 2013). Although previous studies indicate that some benefits associated with pre-chilling treatment for seed germination of Leucaena, however, there is a dearth information concerning germination performance of pre-chilled seeds treated with physical breaking dormancy methods. The present study was carried out with the objective to evaluate the effects of cold water, clipping and immersing in sulfuric acid on germination and seedling growth of pre-chilled seeds of Leucaena.

\section{Materials and Method}

\section{Seed collection}

Mature seeds of Leucaena leucocephala were harvested from the stand growing naturally in Hasanuddin University campus, Makassar, Indonesia $\left(5^{\circ} 10^{\prime} \mathrm{S}, 119^{\circ} 20^{\prime} \mathrm{E}\right)$; with elevation of $7 \mathrm{~m}$ above sea level. Seeds were selected by sorting out the healthy and uniform seeds. Unhealthy and malformed seeds were discarded. Before experiment was conducted, the viability of seeds were tested by floating 


\section{International Journal of Science and Research (IJSR) \\ ISSN (Online): 2319-7064}

Index Copernicus Value (2013): 6.14 | Impact Factor (2014): 5.611

method in tap water. The floated seeds were discarded and assumed not to be viable and only the sunk seeds were used for the study.

\section{Experimental design and treatment}

The experiment consisted of pre-chilling of seeds at low temperature, soaking of pre-chilled seeds in cold water, mechanical and sulfuric acid scarification of pre-chilled seeds.

The experiment was conducted using Completely Randomized Design (CRD) with fourteen treatments and each experiment using four replicates. Each replicate consisted of 15 seeds. The treatments were as follows:

- Freshly harvested seeds (one day after harvest) (T1)

- Pre-chilling of freshly harvested seeds in refrigerator at temperature of $10^{\circ} \mathrm{C}$ for 90 days (T2) (control).

- Soaking of pre-chilled seeds in cold water $\left(28.5^{\circ} \mathrm{C}\right)$ for 24 , 48 and 72 hours (T3, T4, T5),

- Clipping of pre-chilled seed coats at $1-2 \mathrm{~mm}$ around micropyle (T6), $1-2 \mathrm{~mm}$ at distal end) (T7) and rubbed with sand paper for 10 minutes(T8),

- Immersing of pre-chilled seeds in sulfuric acid (96\%) for 4minutes (T9), 8 minutes (T10), 12 minutes (T11), 16 minutes (T12), 16 minutes (T13), 20minutes (T14) and 24 minutes (T15).

The seeds under sulfuric acid scarification was gently stirred periodically and after treatment duration, seeds were washed repeatedly in running tap water until they were considered safe to handle.

\section{Germination and bioassay studies}

Fifteen seeds of leucaena were kept in sterile Petri dish (8 $\mathrm{cm}$ diameter) lined with one layer of filter paper. The filter papers were kept saturated with addition of distilled water throughout the study period. The Petri dishes were put on laboratory bench at the temperature of $28-37^{\circ} \mathrm{C}$ and covered to prevent the moisture loss by evaporation. The germinated seeds were recorded daily until germination ended. After 9 days of incubation, germination indices, radicle length, hypocotyl length and seedling vigor index were recorded/counted. Germination was regarded to have occurred when the radicle was observed. The length of radicle and hypocotyl were measured using ruler by taking five seedlings per treatment at random. When germination percentage was less than $30 \%$, all seedlingswere used as sample.

Germination indices measured were: 1 germination percentage (GP) : number of germinated seeds/total number of seeds in Petri dish, 2 mean daily germination (MDG): total number of germinated seeds/total number of days of germination period, 3 germination speed GS): was calculated following the formula given by Czabator (1962) as follows: $n 1 / d 1+n 2 / d 2+n 3 / d 3+\ldots \ldots \ldots$, where $n-$ number of germinated seeds and $\mathrm{d}$ - number of days, 4 mean germination time (MGT), was calculated following the formula given by Ellis and Roberts (1981):

$$
\text { MGT }=\frac{\sum \mathrm{Ti} \mathrm{Ni}}{\sum \mathrm{Ni}}
$$

Where $\mathrm{Ti}$ is the number of days from the beginning of study and $\mathrm{Ni}$ is the number seeds germinated per day and 5 seedling vigor index (SVI) was determined according to formula given by Abdul-Baki and Anderson (1973) as seedling length $\mathrm{x}$ germination percentage/100

\section{Statistical analysis}

Data obtained were subjected to analysis of variance using SPSS software version 16 and means of parameter measured were tested using Least Significant Difference at 5\% probability level.

\section{Results and Discussion}

The results of the germination test for different methods of breaking dormancy of Leucaena seeds are shown in Table 1. There was no significant difference in germination percentage among some mechanical scarifications, sulfuric acid scarification and control, but germination percentage was significantly higher in sandpapered seeds and lower in freshly harvested seeds and in seeds soaked in cold water than that of control.

\section{Pre-chilling treatment}

The results of germination test for various methods of breaking dormancy are presented in Table 1 . Table 1 showed that dry pre-chilling seeds at $10^{\circ} \mathrm{C}$ for 90 days had positive effect on germination, because it significantly increased their GP, GS, MGT and SGI values by $80,77,52$ and $73 \%$, respectively over those of freshly harvested seeds. The increased seed germination after storing for three months at temperature of $10^{\circ} \mathrm{C}$ indicates that this storage conditions was sufficient to overcome much of the innate dormancy in Leucaena seeds. The increased seed germination as affected by pre-chilling has also been reported in sheep sorrel (Rumex acetosella) (Yadziet al. (2013) and Indian ricegrass (Achnatherum hyenoides) by Scianna et al (2012) .In Leucaena, pre-chilling of seeds kept at $4^{\circ} \mathrm{C}$ for 4 weeks improved germination percentage by 20\% (Omran, 2013). The improved germination might be attributed to increasing level of cytokinin and gibberelline during pre-chilling (Kimbiziet al., 2006) that were absent in un-chilled and dormant seeds (Omran, 2013). Gibberellic acid is known can activate synthesis of protein and other metabolites that are required by the embryo for germination (Golmohammadzadeh et al., 2015).The pre-chilled seed coat of Leucaena also might be thinner than the fresh un-chilled seeds. This is in agree with Omran (2013) that Leucaena had an impermeable seed coat which could breaks down after exposure to the chilling treatment. The positive effect of prechilling to germination is indicative of physiological dormancy (Li et al., 2007).

\section{Soaking of pre-chilled seedsin cold water}

Soaking of pre-chilled seeds in cold water reduced GP, MDG and GS values, but it increased MGT, RL, RL/HL ratio values significantly compared to control (Table 1). The pronounced effect of decreasing GP, MDG, GS values and increasing MGT value was found in 72 hours soaking period. The lower germination in the 72 hours soaking 


\section{International Journal of Science and Research (IJSR) \\ ISSN (Online): 2319-7064 \\ Index Copernicus Value (2013): 6.14 | Impact Factor (2014): 5.611}

treatments might be due to leaching out of soluble food and auxins and the action of bacteria after soaking for a long time (Wheeler, 1965). Besides, it also might be attributed to the reduced concentration and availability of dissolved oxygen in comparison with the air. This is agreement with Amusa (2010) who reported that soaking seeds in cold water reduced germination of Afzeliaafricana seeds due to oxygen deficiency.

In the seeds soaked for 24 and 48 hours, the lower germination percentages were compensated by increasing of RL, RL/HL ratio and SVI value (Table 1). The higher RL and HL values as influenced by soaking in cold water had also been reported by Dezfuliet al. (2008) in maize seedling. This might be due to the involvement of soaking in cell elongation and cell division of meristematic tissues (Khan et al., 2006). The high RL, HL and SVI values are desirable seedling characteristics because they determine initial growth and capability of plant to compete for basic needs of nutrients, water and light.

Table 1: Effect of various pre-treatments on germination indices and seedling growth of Leucaena leucocephala

\begin{tabular}{|c|c|c|c|c|c|c|c|c|}
\hline Treatments & $\begin{array}{c}G P \\
(\%)\end{array}$ & $\begin{array}{c}M D G \\
(\% / d a y)\end{array}$ & $\begin{array}{c}G S \\
(\text { seed/ } \\
\text { day })\end{array}$ & $\begin{array}{c}M G T \\
(\text { days })\end{array}$ & $\begin{array}{c}R L \\
(\mathrm{~cm})\end{array}$ & $\begin{array}{c}H L \\
(\mathrm{~cm})\end{array}$ & $\begin{array}{c}R L / \\
H L \\
\text { Ratio }\end{array}$ & $S V I$ \\
\hline T1 & 10.0 & 2.08 & 0.94 & 4.13 & 6.25 & 5.60 & 1.16 & 1.19 \\
\hline T2 & 83.3 & 16.7 & 4.70 & 2.70 & 4.60 & 4.45 & 1.03 & 7.41 \\
\hline T3 & 73.3 & 14.7 & 4.01 & 3.25 & 7.40 & 5.20 & 1.42 & 9.23 \\
\hline T4 & 75.0 & 15.0 & 4.16 & 3.00 & 7.50 & 4.80 & 1.56 & 9.29 \\
\hline T5 & 56.6 & 5.65 & 2.90 & 3.23 & 7.00 & 4.70 & 1.48 & 6.62 \\
\hline T6 & 80.0 & 13.3 & 4.04 & 3.09 & 6.71 & 3.83 & 1.75 & 8.96 \\
\hline T7 & 85.0 & 14.2 & 5.94 & 2.16 & 5.02 & 4.10 & 1.22 & 7.75 \\
\hline T8 & 88.0 & 17.8 & 4.39 & 2.16 & 7.60 & 4.50 & 1.69 & 10.65 \\
\hline T9 & 78.7 & 15.3 & 4.00 & 3.46 & 0.93 & 3.30 & 0.28 & 3.32 \\
\hline T10 & 83.7 & 14.5 & 3.87 & 3.25 & 0.85 & 3.48 & 0.24 & 3.02 \\
\hline T11 & 84.3 & 13.1 & 4.00 & 3.14 & 0.62 & 3.10 & 0.20 & 2.43 \\
\hline T12 & 84.7 & 13.9 & 4.41 & 3.29 & 0.60 & 2.88 & 0.21 & 2.39 \\
\hline T13 & 85.0 & 14.2 & 4.03 & 3.42 & 0.54 & 2.74 & 0.20 & 2.33 \\
\hline T14 & 35.0 & 5.83 & 1.49 & 3.29 & 0.43 & 2.28 & 0.19 & 0.94 \\
\hline LSD at 5\% & 4.65 & 2.71 & 0.95 & 1.50 & 2.60 & 1.79 & 0.60 & 1.70 \\
\hline
\end{tabular}

\section{Mechanical Scarification}

Among the mechanical scarification treatments, rubbing of pre-chilled seeds around the circumference gave the highest GP, MDG, RL and SVI values. The highest germination percentage as affected by sandpapering had also been reported by Oyebamiji et al. (2014) in Spondias mombin Linn and by Yisau et al. (2015) in Albizia zygia. The highest germination for mechanically scarified seeds around the circumference might be attributed to the closeness of seed's embryo to circumference part of the seeds (Yisauet al., 2015) and provision of largest area for water absorption (Subairu, 2014). Increasing seed germination as resulted from sandpapering of pre-chilled seeds indicates that breaking physical dormancy can be combined with breaking physiological dormancy to increase germination and seedling growth of Leucaena seeds.

\section{Sulfuric Acid Treatment}

Scarification of fresh Leucaena seeds with sulfuric acid with promoting germination results had been reported by Sajjan et al (2000) and Shapo (2015). In the present study, scarification of pre-chilled seeds with sulfuric acid for 4 to
20 minutes seeds had nod no significant effect on germination but it significantly decreased RL, HL, RL/HL ratio and SVI values compared to other treatments. This indicates that sulfuric acid scarification of pre-chilled seeds was ineffective to improve germination of Leucaena. Sulfuric acid scarification even harmed the growth of radicle and hypocotyl, resulting in the low SVI value. The decreased of radicle length with increasing immersion time to sulfuric acid had also been reported by Soomarin et al (2010). The reason for reduced seedling length in sulfuric acid treatments could be the reduction ofmeristematic cells division in radicle and hypocotyl. This might be resulted from the low activity of some hydrolytic enzymes contained in the cotyledon and endosperm. When these enzymes active, they digest the stored food which is converted to soluble form and transported to meristematic tissues. When activities of these enzymes are affected, the soluble food does not reach meristematic tissue and reducing the radicle and hypocotyl length.

Sulfuric acid scarification showed greater toxic effect on radicle length than on hypocotyl length. The reduction in radicle length could be reduced cell division in meristematic zone of radicle. This might due to the fact that radicle is the first organ that absorbs toxic substances from sulfuric acid. Besides, radicle tissue has greater permeability compared to shoot tissue (Nishida, el al., 2005).

\section{Conclusion}

Fresh seeds of Leucaena have dormancy and would not germinate early and easily. Chilling of the seeds for three months at $10^{\circ} \mathrm{C}$ is recommended because it increased germination and seedling growth significantly. Although sandpapering of pre-chilled seeds resulted in higher germination and seedling growth compared to control, but because their differences were not large and sandpapering treatment may be more expensive, pre-chilling of seeds without further treatment may be recommended for largescale seed germination.

\section{References}

[1] Abdul-Baki, A. \& Anderson, J.D. (1973).Vigor determination in soybean seed by multiple criteria. Crop Sci. $13: 630-633$.

[2] Aminah, A. \& Wong, C.C. (2004). Dry matter productivity and nutritive quality of Leucaena hybrid quality for high protein feed production. J. Trop. Agric. Fd. Sci. 32 (2): $251-256$.

[3] Amusa, T.O. (2010). Effects of three pre-germination treatments techniques on dormancy and germination of seeds Afzelia africana. J. Hort. Forestry, 3 : 96 - 103.

[4] Czabator, F.J. (1962). Germination value: An index combining speck and completeness of pine seed germination. Forest Sci. 8: 386 - 395 .

[5] Dezfuli, P.M., Sharifzadeh, F \&. Janmohammadi,M. (2008). Influence of priming techniques on seed germination behavior of maize inbred lines (Zae mays L.).APRN J. Agric. Biol. Sci. 3 (3): 1 - 4.

[6] Ellis, R.H. \& Robetrs, E.H. (1981). The quantification of ageing and survival in orthodox seeds. Seed Sci. Technol. 9: 373 - 409 .

\section{Volume 4 Issue 11, November 2015}




\section{International Journal of Science and Research (IJSR) \\ ISSN (Online): 2319-7064 \\ Index Copernicus Value (2013): 6.14 | Impact Factor (2014): 5.611}

[7] Golmohammadzah, Zaefarian \& Rezvani, M. (2015). Effects of some chemical factors, pre-chilling treatments and interactions on the seed dormancy breaking of two Papaver species. Weed Biol. Managmnt, 15: $11-19$.

[8] Hughes \& Colin, E. (1998). Monograph of Leucaena (Leguminosae-Mimosoideae). Systematic Botany Monograph, v. 55.

[9] Khan, A.A. \& Abawi, G.S., 2006. Integrating matrioconditioning and fungicidal treatment of table beet seed to improve stand establishment and yield.Crop. Sci. 32: $231-237$.

[10] Kimbizi, I., Adebola, P.O. \& Afolayan, A. (2006). Effects of temperature, pre-chilling and light on seed germination of Withania somnifera, a high value medicinal plant. South Afr. J. Bot. 72: $11-14$.

[11]Kumar, B.M., Kumar, S.S. \& Fisher, R.F. (1998). Intercropping teak with Leucaena increases tree growth and modifies soil characteristics. Agroforestry System, $42: 81-89$.

[12]Li, A.R., Guan, K.Y \& Robert, R.J. (2007).Effect of light, scarification and gibberellic acid on seed germination of eight Pedicularis species from Yunnan, China. Hort. Sci. 42: 1259 - 1262.

[13] Nishida, N.S., Tomatsu, N., Nagata, C. \& Sakai,A. (2005). Allelopathic effect of volatile monoterpenoids produced by Salvia leucophylla: Inhibition of cell wall proliferation and DNA synthesis in the root apical meristem of Brassica compestris seedling. J. Chem. Ecol.,31: 1187 - 1203 .

[14] Omran, Z.S. 2013. Effect of mechanical scarification, chilling and gibberellic acid on germination of Leucaena leucaena seeds. J. Biotechnol, Res. Center, 7 (3) : $54-60$.

[15] Oyebamiji, N.A., Fadimu, O.Y. \& Adedire, M.O. (2014). Best pre-germination techniques on Spondias mombin Linn seeds for plantation establishment. American- Eurasian J. Agric. \&Envoron. Sci., 14 (6) : $575-579$.

[16] Sajjan, A.S., Devaranavadgi, S.B. \& Honyal, S.C. (2000). Practical method of Subabul (Leucaena leucocephala (Lam.) de Wit) seed scarification. J. Adv. Forest.Res.in India.23 : $160-164$.

[17] Sanginga, N. Mulongoy, K. \& Ayunaba, M. 1989. Nitrogen fixation of field-inoculated Leucaena leucocephala (Lam.) de Wit estimated by the $15 \mathrm{~N}$ and difference method. Plant and Soil. 117 (2) : $269-274$.

[18] Scianna, J., Jacobs, J., \& Kilian, R (2012). Overcoming seed dormancy in Indian ricegrass (Achnatherum hymenoides). USDA Natural Resources Conservation Service.

http://www.nrcs.usda.gov/Internet/FSE_PLANTMATE RIALS/publications/mtpmctn 11280.pdf

[19] Shapo, H.E. (2015).The effects of pre-sowing treatment on seed germination of of some agroforestry tree species.

http://arcsudan.sd/arc/conferences/meeting46/pdf/10.pdf

[20] Shelton, H.M. and J.L. \& Brewbaker, J.L. (1998). Leucaena leucocephala - The Most Widely Used Forage Tree Legume.In: Forage Tree Legumes in Tropical Agriculture. Ed. R.C. Gutteridge \& H.M.Shelton. Department of Agriculture, The University of Queensland, Australia.
[21] Soomarin, S.J., Alipoor S.H. \& Mahmoodabad, R.Z. (2010). Evaluation of sulfuric acid application in breaking dormancy of goosefoot and red-rot amaranth seeds. Plant Ecophysiol, 2 (2010) : 127 - 131.

[22] Subairu, S.U. (2014). The influence of seed pretreatment on seed germination and seedling vigor in Acacia senegal in the Nurs. J. Biol. Agric.Healthcare, 4 (12) : $57-62$.

[23] Teimouri, M.S., Koochek,A.\& Mahallati, M.N. (2013). Seed germination and breaking dormancy techniques for endemic Hymenocrater platystegius Rech.f. of khorazan Razavi province, Iran. Int. J. Agric. Crop Sci. $6(12): 885-889$

[24] U terMeulen, Struck, S. Schulke, E. \& Harith, E.A.E. (1979). A review on the nutritive value and toxic aspects of Leucaena leucocephala. Trop. Anim. Prod. 4 (2) : $113-126$.

[25] Wheeler, A.W. (1965).The effect of seed treatment on growth and growth substances content of Dwarf French Beans (Phaseolus vulgaris). J. Exp. Bot. 16 : $714-718$.

[26] Yadzi, S.A.F., Rezvani, M., Mohassel, M.H.R. \& Ghanizadeh, H. (2013). Factors affecting seed germination and seedling emergence of sheep sorrel. Romanian Agric. Res. 30: $1-8$.

[27] Yisau, J.A., Aduradola, A.M. Agboola, D.A. \& Jayeola, O.A. (2015). Influence of pre- germination treatments on germination potential and seedling vigour of Albizia zygia (D.C. Macbr). J. Appl. Sci. Environ. Manage. 19 (3) : $397-400$ 